\title{
Fishery resources: between ecology and economy
}

\author{
Angelo Tursi $\cdot$ Porzia Maiorano $\cdot$ Letizia Sion • \\ Gianfranco D'Onghia
}

Received: 27 June 2014/ Accepted: 17 December 2014/Published online: 14 January 2015

(C) The Author(s) 2015. This article is published with open access at Springerlink.com

\begin{abstract}
The complexity in the management of marine biological resources is due to the manifold variables concerning environmental phenomena, technological aspects and socio-economic problems as well as the uncertainties in the assessment of stochastic processes related to the exploited populations. After a short review of the state of art at world level, the authors focus on the Mediterranean and Italian seas providing information on global capture production of fishery resources and economical aspects of fishing activity, raising the need for a management approach that should be robust with uncertainties, suitable for multi-species fisheries and that meets ecosystem objectives. In this respect, the authors report the main recommendations of the Code of Conduct for Responsible Fisheries and measures indicated in the Council Regulation (EC) 1967/2006 and Marine Strategy Framework Directive.
\end{abstract}

Keywords Fishery resources · Ecosystem approach · Management $\cdot$ Ecology $\cdot$ Economy

\section{Fishery resources, fisheries and system complexity}

Fishery resources are represented by populations of animal and plant organisms used by man, especially for human

This contribution is the extended, peer-reviewed version of a paper presented at the conference "Sustainable management of the Mediterranean", held at Accademia Nazionale dei Lincei in Rome on March 212014.

A. Tursi $(\bowtie) \cdot$ P. Maiorano $\cdot$ L. Sion · G. D’Onghia

Department of Biology, University of Bari Aldo Moro,

Via E. Orabona 4, 70125 Bari, Italy

e-mail: angelo.tursi@uniba.it food purposes to produce fishmeal for animal husbandry, aquaculture products as well as crafts and decoration of various kinds.

The populations of aquatic organisms are generated and maintained through complex biotic and abiotic interactions within the marine ecosystem. Their texture and evolution are linked to numerous selective factors that act in the ecosystem (hydrographic conditions, productivity, predation, etc.) and human activities over the past two centuries, first of all fishing. Therefore, in the natural system, governed by the laws of biological evolution, relevant actions affecting population structures and communities of organisms are caused by a single species, man. This fact immediately highlights how the ecological dimensions of natural systems intersect with the social and economic ones of human communities (Cataudella and Spagnolo 2011).

Fishing can be defined as the collection or capture of wild organisms from the oceans, seas and inland waters (lakes, rivers, streams, etc.) and is one of humanity's oldest activities. Fishing is an important economic activity which provides food from the sea and thereby creates employment not only for whoever (the fishermen) directly collects that food (fish, crustaceans, molluscs) but also for those who operate in the entire chain, from the construction of vessels and equipment supplies related to the marketing of products. Therefore, fishing is one of those human activities that includes ecological (about populations and aquatic ecosystems), socioeconomic (those working in the sector), technological (boats, motors, tools, etc.) and, consequently, political and administrative concerns. Organisms exploited by fisheries mainly belong to food chains whose first link is microscopic algae with distribution limited to the availability of light, more or less in the first $200 \mathrm{~m}$ of depth. Primary productivity due to phytoplankton is related not only to the availability of light but also to that of nutrients 
(nitrogen, phosphorus, iron, etc.) as well as to particular subsidiary energy sources (upwelling currents, tidal flows, etc.). Estimates by Pauly and Christensen (1995) indicate that on average $8 \%$ of the global primary productivity of the sea supports global fishing or, in other words, this is the percentage of primary productivity that becomes food for humans. This percentage drops in the open ocean (approximately $2 \%$ ) and increases in coastal areas and in areas with rising currents (between 24 and $35 \%$ ), confirming the increased productivity of these latter environmental systems in terms of resources exploited by man.

The study of fishery resources implies a substantial leap in the complexity typical of ecological studies of the connection and interaction between the parties (living forms as well as physical, chemical and biological factors, climatic conditions, etc.) which determines a unique and unrepeatable scenario. The study of relations and connections between natural phenomena on different space-time scales requires the integration of different scientific disciplines. Economics and social sciences play an important role in issues related to the management of fisheries' resources.

\section{Fishery resource management: between ecology and economy}

Over the millennia and until the nineteenth century, man could not even remotely conceive that our actions could result in the depletion or even the extinction of exploited populations and indeed believed that fish stocks were inexhaustible and so all that was necessary to collect a larger amount was to spend more time and improve the means employed in their procurement, i.e., increase the socalled "fishing effort". In fact, while the populations of aquatic species are renewable, they are not inexhaustible. The exploitable fraction of the population is defined as the "stock" and is characterized by its own dynamics related to the contribution of new individuals (recruitment) and their growth as well as the mortality rate of individuals. This latter is both by nature and in relation to the capture of individuals by the fisheries (fishing mortality). The increase in catches occasionally recorded in some areas is generally due to the increase in the fleet and improved fishing technology rather than to greater availability of resources in the sea. According to the latest statistics, the total world production was 158 million tonnes in 2012, of which 91 million tonnes referred to fishery captures and 67 million tonnes to aquaculture production (FAO 2014). The fishing effort maintained at high levels may result in the collapse of one or more resources in the distribution areas. Currently, over $70 \%$ of world fish stocks are fully exploited, about $20 \%$ overexploited and only $10 \%$ of stocks are underexploited by fishing (FAO 2014).
An unregulated fishery causes overfishing of resources both in biological and economic terms. In bio-ecological terms, overexploitation of resources can cause not only the depletion of stocks of the species of interest to fishing activity (target species) but also of many others of lower or no economic value, but nevertheless important ecologically, caught accidentally together with the first. The main objective of fisheries' management has been to safeguard fish stocks or, in other words, find a level of exploitation that could provide the maximum yield by weight in a lasting way or maximum sustainable yield (MSY). In parallel, in economic terms, the main objective is the achievement of maximum sustainable economic performance or MSE (King 1995). In the face of the different issues concerning the fisheries, management objectives at present, in addition to the protection of individual stocks affected by fishing, extend to the protection and preservation of species and the marine ecosystem to maintain economic viability as well as the preservation of jobs.

\section{The situation in the Mediterranean basin}

The Mediterranean is a semi-enclosed sea with not only high variability of coastal morphology and a high diversity of habitats and living resources mainly on the continental shelf (on average within $200 \mathrm{~m}$ of depth), but also a high diversity of anthropic pressures (civil and industrial discharges, farming and livestock, fisheries, coastal tourism, marine traffic, etc.). Its waters are considered "oligotrophic" that is poor in nutrients, and thus not very productive. Nevertheless, fishing activity has ancient traditions with very high-value resources and diversity of species. In fact, the Mediterranean fishery is known to be multi-specific, because the commercial catches are characterized by a high number of species, contrary to North Atlantic fisheries which maximize the capture of single stocks. In Mediterranean, the monospecific catches occur with small and large pelagic fish. Therefore, this semi-enclosed basin characterized by mainly multispecific catches but also by artisanal or coastal activity results to be a mosaic with many diversified fisheries and gears, along more than $45,000 \mathrm{~km}$ of coastline (Lleonart and Maynou 2003; Relini 2003).

The fishery resources are constituted by five different groups with different problems and issues: small pelagics, large pelagics, demersals, bivals (mussels, oysters, clams) and others (sponges, coral, algae etc.). Small pelagics provide large catches based mainly on sardine (Sardina pilchardus) and anchovy (Engraulis encrasicolus). The most abundant species among large pelagics are bluefin tuna (Thunnus thynnus) and swordfish (Xiphias gladius) principally caught by the industrial fleet working in the 
Mediterranean. Demersal resources constitute about $55 \%$ of the Mediterranean catch and represent those organisms which live and feed close to the seabed. About a hundred of species are exploited and the most important are: hake (Merluccius merluccius), greater forkbeard (Phycis blennoides), blue whiting (Micromesistius poutassou), red mullets (Mullus surmuletus and M. barbatus), red shrimps (Aristeus antennatus and Aristaeomorpha foliacea), Norway lobster (Nephrops norvegicus), rose shrimp (Parapenaeus longirostris) and some cephalopods (Octopus, Sepia, Eledone, etc.). The fleets fishing on the small pelagic and demersal stocks is semi-industrial or artisanal (Lleonart and Maynou 2003; Relini 2003).

In the Mediterranean-Black Sea, declining catches were observed, with decreases of 15 and $30 \%$ since 2007. The Global Capture Production of fishery resources (fish, molluscs, crustaceans) was about 1.4 and 1.2 million tonnes in the 2011 and 2012, respectively, observing a variation of less $10.8 \%$ (FAO 2014). Although, this amount seems to be negligible with respect to the world catch, its average economic value is generally greater than that at world level. For example, the Mediterranean fisheries provide about $20 \%$ of the total catch in weight of the European Community but $35 \%$ of the total economic value (Lleonart and Maynou 2003).

From the 1950s, fishing activities have been extended toward deeper grounds, as deep as 700-800 $\mathrm{m}$ in many Mediterranean basins, with the aim of increasing the capture of living resources. This has occurred mainly along the Spanish coasts, in the Tyrrhenian Sea, Sicilian Channel and Ionian Sea.

On the basis of the latest data, most of the stocks of the Mediterranean are either fully exploited, or overexploited. Particularly hake (Merluccius merluccius) and red mullet (Mullus barbatus) stocks are considered overexploited. The main stocks of small pelagic fish (sardine and anchovy) are assessed as either fully exploited or overexploited. In general, the Mediterranean and Black Sea had $52 \%$ of assessed stocks fished at unsustainable levels, and $48 \%$ fully or underfished in 2011 (GFCM 2011; FAO 2014).

The Mediterranean aquaculture production has increased extensively over the past 10 years $(25 \%$ per year). Presently, aquaculture production is more than 200,000 tonnes per year for marine production and more than 500,000 tonnes for brackish water production (without the freshwater production, which is also quite important in countries such as Egypt, Turkey and Italy). It complements fisheries' production and is becoming one of the main sources of aquatic products for many countries of the Mediterranean (GFCM-General Fisheries Commission for the Mediterranean 2011).

With the Italian law relative to the rationalization and development of sea fishing (Law n. 41, 17.02. 1982 Piano per la razionalizzazione e lo sviluppo della pesca maritti$m a$ ) no longer in force, systematic studies were promoted by the then Ministry of Merchant Navy (now Ministry of Agriculture, Food and Forestry Policy) to monitor the distribution, abundance and exploitation status of the fishery resources in the Italian seas. Thus, the knowledge on the bio-ecology of many species has been acquired in the Italian basins where fishing techniques and typologies often reflect resource distribution and availability. Some of these studies are still ongoing and they are currently funded by the European Union. In particular, the European Commission has financed the MEDITS project (Bertrand et al. 2000) since 1994 (International bottom trawl survey in the Mediterranean) which regards the demersal resources of the Northern Mediterranean basins and several Member States. Since the year 2000, some EC Directives (e.g., EC Reg. 1543/2000, EC Reg. 1639/2001) have implemented the "Data Collection" program in the Member States, including MEDITS and other projects aimed at the assessment and management of the marine living resources in the European seas.

\section{Ecosystem Approach to Fisheries (EAF)}

Taking into account the fishing effects on organisms, populations and ecosystems, the exploitation of living resources represents one of the environmental issues now tackled on a global scale and according to the principles of sustainability. In fact, most aquatic ecosystems are affected by fishery activities that involve a selective removal of part of the natural production for human subsistence, economic returns and development.

To promote long-term sustainable fisheries, in 1995 the FAO Conference adopted the Code of Conduct for Responsible Fisheries (FAO 1995). The need for an integrated approach for the management of marine resources, in the broadest sense of the word, finds in the Code a summary of how to achieve long-term sustainable use of fisheries' resources in terms of food, employment, recreation and trade as well as ecosystem and socio-economic well-being of populations throughout the world. Even though certain parts of the Code are based on relevant rules of international laws, it is voluntary and provides principles and standards applicable to the conservation, management and development of all fisheries. It also covers the capture, processing and trade of fish and fishery products, fishing techniques and effort, aquaculture and fisheries' research. The Code has been adopted by the over 170 member Governments of the FAO Conference. Its application will be effective when the member Governments translate its principles and objectives into relevant policies and legislation. 
The international conventions adopted over the last two decades, including the Code of Conduct for Responsible Fisheries, consider the exploitation of living resources on an ecosystem basis; they stress the need for the adoption of an ecosystem approach to fisheries (EAF). The principles of an EAF are an extension of the conventional principles for sustainable fisheries' development to cover the ecosystem as a whole (Garcia et al. 2003). This implies sustainable management not only of the commercial stocks but also of the whole environmental system which supports their production, including the importance of the economic and social dimension (Spagnolo 2006).

The EAF foresees the integration of different practices and measures to deal effectively with complex situations with respect to a variety of needs and demands, from ecological to socio-economic. The EAF aims to achieve an equilibrium between conservation and sustainable use of biological diversity. In particular, it attempts to satisfy the three components of sustainability, which are the ecological dimension (effectiveness-reproducibility of resources), the economic dimension (efficiency) and the social dimension (equity).

Although the beginning of a Common Fishery Policy (CFP) goes back to the 1980s, the Green Book on the future of the CFP was only presented in 2001 on the basis of the Code of Conduct for Responsible Fisheries. This document identifies the limits of the fishery policy that have been adopted by the European Community and the principles on which to base the reform process of the fishery and aquaculture. In this respect, EC Regulation 2371/2002 strongly promotes the sustainable exploitation of resources from a socio-economic as well as an ecological point of view. Even more importantly, EC Regulation 1967/2006, concerning management measures for the sustainable exploitation of fishery resources in the Mediterranean Sea, puts in place the Action Plan for the Mediterranean Sea as part of the Common Fishery Policy (Cataudella and Spagnolo 2011; Cataudella et al. 2011).

With this Regulation, new rules were established for the protection and conservation of Mediterranean resources in reference not only to commercial species but also to protected species and sensitive habitats. The recommendations of the General Fisheries Commission of the Mediterranean (GFCM) and the International Commission for the Conservation of Atlantic Tuna (ICCAT) as well as the measures of species protection and habitat conservation reported in the Habitat Directive (92/43/ EEC) and in the Barcelona Convention are included in the Regulation.

EC Regulation 1967/2006 finally acknowledges that the biological, social and economic characteristics of the Mediterranean fisheries require the Community to establish a specific management framework (EC Reg. 1967/2006).
The regulation of fishing effort is the main measure to favor sustainable fishing in the Mediterranean. In particular, taking into account the differences in the distribution of living resources between the various geographic areas and the consequent different fishing techniques and traditions, the regulations provide for the establishment of Community and National Management Plans, combining the regulation of the fishing effort with specific technical measures (EC Reg. 1967/2006).

Other important measures have been foreseen by the EC Regulation (1967/2006). In particular, the excessive catches of undersized individuals should be avoided. Thus, it is necessary to protect certain areas where juveniles (nursery areas) or adults (spawning areas) congregate. Fishing gears that are too harmful to the marine environment or lead to the depletion of certain stocks should be prohibited or more strictly regulated. To avoid further increases in mortality rates for juveniles and to reduce the amount of discards of dead marine organisms by fishing vessels, it is necessary to increase the selectivity of the currently used gear that is to increase the mesh sizes for trawl nets and bottom-set nets and hook sizes for longlines.

The new regulations will require the establishment of "No-take" marine reserves and management measures to protect the growth and spawning areas as well as the marine ecosystem from destructive fishing effects.

"No-take" marine reserves are considered as an additional form of fisheries' management based mostly on general principles, including ecosystem functions, overall public interest and the need for insurance against the complexity of the environment and socio-economic system. In this regard, starting from 1998, the Ministry of Agriculture, Food and Forestry Policy (MiPAAF) decreed, as part of the protection plan of the fishery resources, the institution of "no-take zones" (Zone di Tutela Biologica, ZTB) where fishing is not allowed and/or regulated during critical phases (spawning, recruitment, feeding, etc.) of the demersal stocks distributed there, with the aim of allowing the renewal of the stocks and their sustainable exploitation in neighbouring areas.

Such no-take zones should correspond to areas which play a fundamental role in the life cycle of one or more demersal species of economic interest. In other words, they would correspond to areas where species concentrate for different biological reasons and whose protection could enhance the management effect through their closure to fisheries. Although some 'no-take zones' were identified along the Italian coast, no data on their effect on the fishery resources are yet available.

The multi-species nature of Mediterranean fisheries, in terms of both species and fishing gears, requires a specific strategy able to combine and integrate the different management measures to preserve flexibility in the fishing 
activity. In this way, the alternative adoption of a 'closed season' in different areas or catch restrictions and gear limitations together with the main regulation of reducing the fishing effort could avoid the overexploitation of marine resources.

\section{Alternative income-generating fishing activities}

Overexploitation of marine resources has lead to the decline of many demersal stocks as well as to habitat degradation, which is particularly severe in marine coastal zones, where human activities have historically been concentrated. In fact, the increasing discharges of waste and materials from the coast, pollution as well as urban and tourism developments have often led to definitive loss of natural habitats that has severe implications in the coastal small-scale fishing activity and consequent economic and social effects. Apart from the regulation of fishing activities previously reported and the protection and conservation of marine habitats, the promotion of alternative actions has been developed in recent years to transfer fishermen from fishery to tourist activities. In particular, the Ministerial Decree 293/99 regulates "fishing tourism" which represents fishing activity for tourist and educational services with which the local fishing community can supplement its income. Fishing tourism is the best way to participate in local development while also integrating socio-economic and cultural activities. Tourist fishing aims not only to discover the resources of the sea, but also to teach people how to experience and respect nature. It is the best way to learn the culture of the sea and of fishing, coastal areas and lagoons, as well as to discover the ancient professions and traditions while also eating excellent fresh fish cooked on board. In fact, aboard a traditional fishing boat everybody can learn from the ancient heritage of fishing techniques and Italian traditions, in the same way as in a museum or a natural park. Moreover, the fishing tourism activity prolonged to different seasons could contribute to the seasonal adjustment of the tourism flow, also reducing resource exploitation in the critical period.

By means of this activity, fishermen could decrease their total fishing effort and be directly involved in the local socio-economic development. The gradual decrease of the main fishing activity produced by the fishing tourism could guarantee sustainable management of resources and/or habitat maintenance either directly through a contribution to conservation and/or indirectly by providing revenue to the local community sufficient for local people to value, and therefore protect, their wildlife heritage as a source of income. An additional important contribution that the fishing world can offer is related to the growth of tourism centered on traditional local products and local cuisine, as well as various activities in which the tourist takes an active role in demonstrational fishing activities, also proposing the start-up of new services, such as fishing tourism, whale-dolphin watching and environmental education.

Human impact leads to decreasing diversity of habitat and species as well as to changing the population and community structure with a severe effect on ecosystem functions.

Although the institution of Marine Protected Areas (MPAs) along the Italian coasts is regulated by the Ministry of the Environment for biodiversity protection and nature conservation and not for fisheries' objectives as in other countries, the MPAs also represent an available and promising management strategy for sustainable use of marine resources. Mediterranean MPAs provide crucial goods and services that support local communities and economies, including recreational and tourist opportunities, producing social and economic development and other benefits. They could also promote environmental education and research. Moreover, MPAs maintain high productivity and high diversity in marine ecosystems, provide a refuge for the conservation of unique species and habitats as well as for exploited species allowing them to recover, increase biomass and restock fishing grounds through the spill-over of egg-larvae, juveniles and adults to replenish commercial stocks in the adjacent fisheries.

Even though each of these areas can have limited relevance when considered in isolation, all of them together (in an MPA network) can contribute effectively to safeguarding the marine environment, also thanks to the spill-over effect for species covered by the analysis.

An MPA must involve local institutions, as well as stakeholders (fishermen, shipbuilders, tourist cooperatives, etc.). The management and the control of the area should benefit from the active involvement of stakeholders (especially fishermen), who should collaborate with the entities in charge of controlling the area (Coastal Guard, etc.), motivated by a direct economic advantage for them. Collaboration between the various actors involved is a necessary condition to promote a sustainable process for fishing, which marries the need for economic development with that of protecting the environment. There is no question that the first step towards establishing the right relationship between the MPA management and the fishing world is that of sharing rules based on shared understanding and shared planning of the goals and potential of the MPA. In any case, managerial uncertainty can also be caused by the efficacy of the checks with regard to the various anthropic impacts, and not only those of fishing, which may take place in the area. In particular, fishermen's involvement can involve: (a) participation in the definition of areas and perimeters, (b) identification and sharing of management practices, (c) implementation of 
environmental protection activities and surveillance in the MPA territory.

\section{Strategies for the marine environment and the ecosystem approach}

Some of the above-reported managerial strategies favour the involvement of users and administrators at the same time. They also have the important impact of embedding ecosystem objectives, which take into account the complexity of the resource-environment system.

As stated in the framework document, it is commonly understood that pressures on natural marine resources and demand for marine ecosystem services are often too high and, therefore, that the need for a reduction in their impact on marine waters, regardless of where their effects are felt, is ever more urgent. On the other hand, the marine environment is a precious asset which needs to be protected, defended and where possible restored, to keep biodiversity and protect the diversity and livelihood of seas and oceans which need to be clean, healthy and productive. To meet these needs, on June 172008 the European Parliament and the EU Council issued the framework Directive on the Strategy for the Marine Environment (EC Reg. 2008/56), which was then considered in Italy when issuing law n. 190 on October 132010.

The EU Directive is based on an integrated approach and aims to become the environmental pillar of the future marine policy of the EU. The Directive sets the goal of Good Environmental Status (GES) for their marine waters for member States to reach by 2020. To reach GES, each member-State has to develop a marine strategy which must be agreed with neighboring member States and third countries.

Avoiding loss of diversity is the fundamental goal today, not only for the marine framework directive but also for the EU. Keeping biodiversity is a fundamental requirement to reach GES for marine waters. The marine protected areas (MPAs) represent an important tool to guarantee long-term conservation of nature and of ecosystem services. To guarantee biodiversity, the human component, and the tight connection between the coastal marine system and the cultural, social and economic context of the local communities cannot be underestimated. The biological benefits of MPAs could become secondary, if the social and economic situation of their territory is not taken into account.

Furthermore, the framework tries to ensure the sustainable utilization of marine goods and services through an ecosystem approach to managing human activities, i.e., a methodology which sees the human community as an integral part of ecosystems and of the systems which rule them.
Finally, returning to the starting point for this document, the ecosystem approach is the underlying principle of the (EC Reg 2008/56) Marine Framework Directive, which was originally summarized in 12 principles, and can be grouped in the following three key points: (1) The communities who live in an area are responsible for the biodiversity that surrounds them. (2) Sustainability is based on three pillars: environmental, economic and social-cultural. (3) To manage an environment, it is necessary to have an understanding of both scientific aspects and local traditions.

Open Access This article is distributed under the terms of the Creative Commons Attribution License which permits any use, distribution, and reproduction in any medium, provided the original author(s) and the source are credited.

\section{References}

Bertrand JA, Gil de Sola L, Papaconstantinou C, Relini G, Souplet A (2000) An international bottom trawl survey in the Mediterranean: the MEDITS programme. Actes de Colloques IFREMER 26:76-93

Cataudella S, Spagnolo M (2011) The multidimensionality of fisheries: a brief introduction. In: Cataudella S, Spagnolo M (eds) The State of Italian marine fisheries and aquaculture, 1. Ministero delle Politiche Agricole Alimentari e Forestali (MiPAAF), Rome (Italy), pp 3-8

Cataudella S, Ferraioli O, Lariccia M (2011) L'evoluzione della pesca italiana verso la sostenibilità nel quadro del Codice di condotta per la pesca responsabile (FAO), della Politica Comune della Pesca (PCP) e della Politica marittima integrata. In AA.VV. (2011) Lo stato della pesca e dell'acquacoltura nei mari italiani, a cura di Cataudella S e Spagnolo M. Ministero delle politiche agricole alimentari e forestali. p 11-31

EC Reg. 1543/2000 of 29 June 2000 establishing a Community framework for the collection and management of the data needed to conduct the common fisheries policy. http://eur-lex.europa.eu/ legal-content/EN/TXT/?uri=CELEX:32000R1543

EC Reg. 1639/2001 establishing the minimum and extended Community programmes for the collection of data in the fisheries sector and laying down detailed rules for the application of Council Regulation (EC). http://eurlex.europa.eu/LexUriServ/ LexUriServ.do?uri=OJ:L:2001:222:0053:0115:EN:PDF

EC Reg. 2371/2002 on the conservation and sustainable exploitation of fisheries resources under the Common Fisheries Policy, http:// eur-lex.europa.eu/legal-content/en/ALL/?uri=CELEX:32002 R2371

EC Reg. 1967/2006. Misure di gestione per lo sfruttamento sostenibile delle risorse della pesca nel Mar Mediterraneo e recante modifica del regolamento (CEE) 2847/1993 e che abroga il regolamento (CE) 1626/1994. http://eur-lex.europa.eu/LexUri Serv/LexUriServ.do?uri=OJ:L:2006:409:0009:0064:IT:PDF

EC Reg. 2008/56 Establishing a framework for community action in the field of marine environmental policy (Marine Strategy Framework Directive).http://eur-lex.europa.eu/legal-content/EN/ TXT/?uri=CELEX:32008L0056

FAO (1995) Code of Conduct for Responsible Fisheries. Rome FAO (2014) The State of World Fisheries and Aquaculture. Rome

Garcia SM, Zerbi A, Aliaume C, Do Chi T, Lasserre G (2003) The ecosystem approach to fisheries. Issue, terminology, principles, 
institutional foundations, implementation and outlook. FAO Fisheries Technical Paper, N. 443. FAO. Rome, p 71

GFCM (General Fisheries Commission for the Mediterranean) 2011. Performance Review of the General Fisheries Commission for the Mediterranean and Black Sea [online]. [Cited 28 November 2011]. http://151.1.154.86/GfcmWebSite/GFCM/35/CAF_II_ 2011_Inf.5_COC_V_Inf.4_GFCM_XXXV_2011_Inf.8.pdf

Habitat Directive (92/43/EEC) on the conservation of natural habitats and of wild fauna and flora. http://eur-lex.europa.eu/legalcontent/EN/TXT/?uri=CELEX:31992L0043

King M (1995) Fisheries biology, assessment and management. In: Fishing News Books. Blackwell Science, p 341

Law n. 41, 17.02.1982 Piano per la razionalizzazione e lo sviluppo della pesca marittima. http://www.normattiva.it/uri-res/ N2Ls?urn:nir:stato:legge:1982-02-17;41@ originale
Lleonart J, Maynou F (2003) Fish stock assessments in the Mediterranean: state of the art. Scientia Marina 67(Suppl. 1):37-49

Ministerial Decree 293/99 on fishing tourism. http://www.europalex. kataweb.it/article_view.jsp?idArt=24953\&idCat=374

Relini G (2003) Fishery and Aquaculture Relationship in the Mediterranean: Present and Future. Mediterranean marine science 4(2):125-154

Pauly D, Christensen V (1995) Primary production required to sustain global fisheries. Nature 374:255-257

Spagnolo M (2006) Elementi di economia e gestione della pesca. (Ed). FrancoAngeli, Milano, p 279 